\title{
Caravans from South Arabia: Roads and Organization
}

In his contribution to the famous volume The Invention of Tradition, the historian Hugh TrevorRoper observed that "the sea unites rather than divides" (Trevor-Roper 1983:15). The same could be said of deserts, provided there are sufficient pack animals - in our case camels - and enough wells, reservoirs etc. In consequence, under certain circumstances the bleak surfaces of deserts may become rather advantageous highways. ${ }^{1}$ The different nature of the regions - deserts, towns, agricultural areas - through which camel caravans traveled imposed different constraints and necessities on animals and humans. In the desert, there is usually room enough for the animals and people to travel alongside one another, at least to some extent, but at the watering places there had to be some kind of organization, of sequence, because understandably not all animals could drink at the same time. Moreover, there had to be animals to carry the caravan's fodder: thus, a certain number of the camels could not be used to transport goods. In addition, few inhabited places along the way through deserts offered any chance of trade. Consequently, desert routes were ideal for fairly fast travel with only the most necessary interruptions. Thus caravans of pilgrims to the holy cities of Islam or the transport of goods such as incense destined, for example, for the Mediterranean region presumably tended to use these rather direct ways. Examples of long-distance routes of this kind are the Basra-Mecca route, the Syrian route to Mecca and the Kufa-Mecca route (cf. Al-Rashid 1980 for research on the "Darb Zubayda", as the Kufa-Mecca route was called; Halm 1991:174).

Yet not all camel caravans traversed deserts: in the south-west of the Arabian Peninsula they used routes through relatively densely populated, intensively cultivated areas, entailing their own special problems, needs and advantages. Few historical sources address this matter in detail. Fortunately, there is a description of the organization of caravans from South Arabia to the north originating from the 10th century.

In the first part of the following contribution, I shall try to characterize the different possibilities to travel from the southernmost parts of today's Yemen to the south-western provinces of Saudi Arabia (in short: south-western Arabia). I am concerned here with land-based travel only, the important possibility of using boats on the Red Sea will not be included. In the second part of my paper, al-Hasan al-Hamdānī, a South Arabian author who lived in the 10th century, will be my main point of reference, and I shall let him speak about the organization of South Arabian caravans using the highland route in south-west Arabia.

\section{TRADE AND PILGRIM ROUTES IN THE SOUTHWEST OF THE ARABIAN PENINSULA}

As early as pre-Islamic times, the Incense Road - mainly a trade route - led through the Arabian Peninsula running roughly from north to south (Groom 1981; esp. 165-188), thus traversing the region of south-western Arabia. It was already mentioned in antiquity by Eratosthenes of Cyrene (around 225-195 BCE, cited by Strabon), Agatharchides of Cnidos (2nd half of 2nd century BCE, cited by Strabon), Strabon (around 63 BCE-23 CE) and Pliny the Elder (around 23-79 $\mathrm{CE}$ ). Since Islamic times, these north-south routes gained additional importance through the annual pilgrimage: pilgrims traveling to Mecca used the same roads as traders, scholars and diplomats. The old Incense Road at least in south-western Arabia had used the western fringe of

\footnotetext{
${ }^{1}$ I would like to thank the organizers of the conference and editors of the publication, and Andre Gingrich (Vienna) for his helpful comments on a previous draft of this text.
} 
the central Arabian Desert, touching Mārib and Najrān (de Maigret 1997, 2003). By contrast, in a process of hundreds of years, by the 10th century the core area of the south Arabian populace had moved to the west, roughly to the Yemeni highlands, where the population density remains the highest until today. The main north-south roads largely followed this western movement. By the 10th century at the latest there were three main routes from north to south (apart from the Red Sea), each with its own advantages and dangers. A fourth road seems to have gained importance slightly later.

Arab authors dealing with geography, administration and postal routes mention a few places along these southern roads, but usually give no detailed descriptions, no information on distances or the organization of caravans (e.g. Ibn Hurdadbih, Ibn Rusta, Qudāma, al-Ya'qūbī). Only two South Arabian authors described these roads in more detail: the younger was Najm al-Dīn 'Umāra b. 'Alī al-Hakamī in his Kitāb al-Mufìd fì ahbāar Șan 'ầ' wa-Zabìd; written 1167/68 CE). In a chapter on the South Arabian ruler Husayn b. Salāma (reigned 100-1018 CE) he wrote about the construction projects this governor of the Yemen carried out along the roads leading from south to north. ${ }^{2}$ The other author was Abū Muhammad al-Hasan al-Hamdānī (who lived around 893 until 950/60 CE) in his Șifat Jazirat al- 'Arab (Description of the Arab Peninsula), where he dedicated a chapter to the roads he calls mahajja or pilgrim's road. Both authors describe several routes that could be used in their time to travel from south to the north or vice versa.

One of these trade and pilgrim roads through the Arabian Peninsula (see graph 28, road no. 2) followed the Red Sea coast as closely as possible and was called al-tarīq al-sāhiliyya ('Umara 1979:76) or țarīq al-sāhil (al-Hamdānī 1974:341) or țarīq Tihāma (al-Hamdānī 1974:341, 'Umāra 1979:76). It touched villages and harbor towns such as al-Muhāa and the now abandoned Šarja. These settlements offered the additional advantage of trading possibilities, as well as the interchange with the flow of goods transported via the Red Sea, but in summer this coastal area is too hot to travel, at least in the daytime.

The second route led through the highlands, where most of the Yemeni people lived in alHamdānī's time, as they still do today. There, principal administrative centers and important markets present possibilities for trade; there is enough water for the animals of a caravan as well as fodder. Along routes in the desert or - to a lesser degree - on the coast of the Red Sea (the Tihāma), some of the animals of a caravan had to be used to carry fodder. By contrast, the use of the upper, highland or mountain road (see graph 28, road no. 4) - al-țarìq al- 'ulyā ('Umāra 1979:76) or tarīq Najd (al-Hamdān̄̄ 1974:339) or țarīq al-jibāl ('Umāra 1979:72), as it was called - minimized this additional necessity. In contrast to desert routes, the mountain road (and roads with similar characteristics) were advantageous for rather slow travel, for doing additional business on the way, and for the "search for knowledge" that many scholars/pilgrims undertook.

A third route, the lower road or al-tarìq al-suflā (al-Hamdānī 1974:342; see graph 28, road no. 5) led along the fringe of the desert in the east, thus at least in the south having the characteristics of a desert road. It touched on the former South Arabian population centers and possibly constituted the main course of the Incense Road in pre-Islamic times. ${ }^{3}$

An additional route, called al-jādda al-sulțāniyya (the Sultān's highway, see graph 28, road no. 3) or al-tarīq al-wusțā (the middle way; 'Umāra 1979:72), was not yet mentioned by alHamdani in the 10th century. It appears for the first time in the History of the Yemen by 'Umāra b. 'Alī al-Hakamī (who lived from 1121 to 1173/4). This road seemingly was therefore estab-

\footnotetext{
2 Bulliet (1990:228) states quite categorically: "References to the upkeep of roads are almost nonexistent", a statement which contradicts mentions of construction and restoration of roads not only concerning South Arabia, cf. Al-Rashid 1980:8; 11-12; 375, Plate XIII,2; 376, Plate XIV, 2; 385, Plate XXIII, 1, to name just a few examples. In Yemen, the pre-islamic ruler As' ad al-Kāmil is said to have built roads, cf. Ibn al-Mujāwir 1986:203.

3 The old Incense Road led from ancient Qana (Bi'r 'Alī in today's South Yemen) to Šabwa, the capital of the old kingdom of Hadramawt. "From there, passing through the capital cities of the kingdom of Qatabān, of Saba' and of Ma īn (Timna', Mārib and Qarnāw respectively), it reached Najrān, beyond the northern border of today's Yemen” (de Maigret 1994:316; cf. Groom 1981:165-188).
} 
lished slightly later than the other three. Like the first, the tarīq al-sāhil, it went through the Tihàma (the coastal plain of the Red Sea), ${ }^{4}$ but on its eastern fringe near the steep mountain slopes leading up to the central highlands. Towns and marketplaces (e.g. Zabìd or al-Mahjam) could be touched there, but the climatic difficulties are nearly the same as on the coastal road.

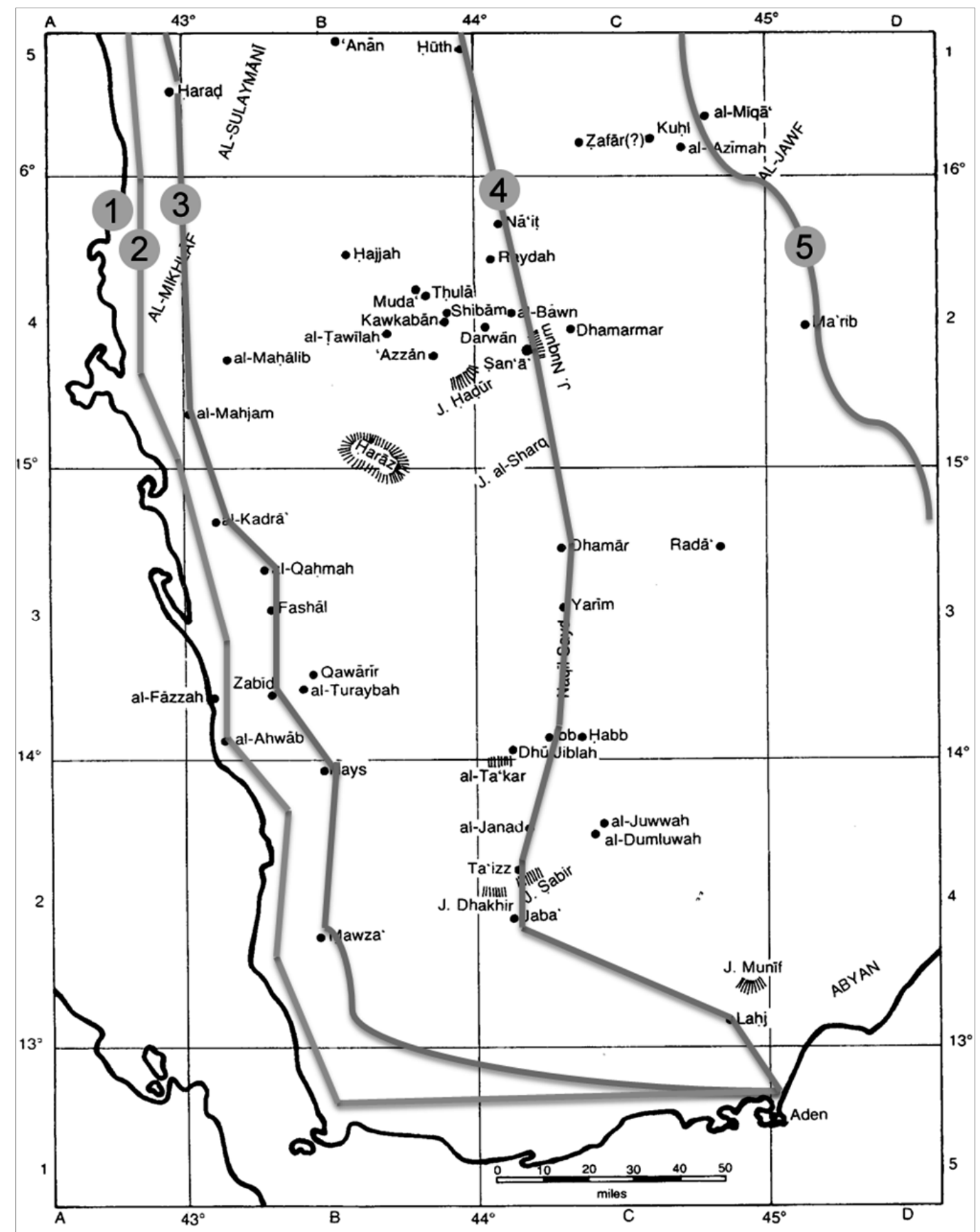

Graph 28: Sketch of trade and pilgrim routes in South Arabia (from left to right):

1 coastline

2 the coastal road, al-țarīq al-sāhiliyya or țarìq al-sāhnil or țarīq Tihāma

3 the Sultān's highway, al-jādda al-sulțāniyya

4 the upper road, al-tarìq al- 'ulyā, țarīq Najd or țarīq al-jibāl

5 the lower road, al-țarìq al-suflā

\footnotetext{
${ }^{4}$ For a more detailed discussion of human/camel interaction in the Tihāma region see the article by Andre Gingrich
} in this volume. 
Between these four main possibilities of north-south travel through the Arabian Peninsula and vice versa there were east-west connections, for instance between the city San' $\bar{a}$ ' and the coast of the Red Sea or in the north between Șa da and Najrān. These east-west routes were certainly not only necessary to find additional trading possibilities but also to avoid stretches of the north-south connections that were impassable or unsafe because of wars, floods and other incidents. Thus a grid of routes was constituted, parts of which are still in use today as roads for motor vehicles. Consequently, the route to take seems to have been largely a strategic consideration for the caravans' leaders, owners or investors. Ecological-climatic problems such as the heat in Tihāma, or rain and floods in the highlands had to be taken into consideration as well as possible political obstacles such as war and unrest, and, last but not least, economic negotiations about the kind of goods or people transported influenced decisions over the route.

\section{MEASUREMENT OF DISTANCES: MILES, DAYS AND POST-STATIONS}

In his Description of the Arabian Peninsula al-Hamdānī tells us a great deal about traveling on these roads, e.g. about how distances were measured. In describing the routes, al-Hamdānī uses three different units of measurement: the first is marhala (pl. marähil), a day's journey, whereby a manzil, pl. manäzil, or "stopping place" is the locality at the end of a marhala). The second we all know, because the word is a very common Latin loanword and therefore in use in many regions; it is the mile ( $\operatorname{arab} . m \bar{\imath} l$, pl. amy $\bar{a} l$ ). The third is barìd, pl. burīd, the post-stations, where official messengers changed horses. al-Hamdānī divides the way between Șan'à' and Mecca into 22 marāhhil (day's journeys), which correspond to 35 burüd or postal stations and to 420 amyāl or miles. From the information about distances one can derive two fixed measurements: one barìd corresponds exactly to 12 miles (between 23 and 24 km; cf. W. Hinz 1991 in: EI2, 2:232; s.v. dhirā'). But understandably, the marāhil or day's journeys differ with respect to the terrain. On average, one marhala corresponds to 19 miles or 1.6 burüd (around $37 \mathrm{~km}$ ). But in spite of that it remains unclear to me how far in terms of modern measurement the distance of a mile really was for al-Hamdānī. Richard W. Bulliet (1990:227) mentions that "a regular daily stage of travel for a caravan does not exceed twenty miles", resulting in $31 \mathrm{~km}$, but he gives no consideration to terrain. On the south-west Arabian highland road it could have well been less.

When traveling north, stars could be used for orientation. Between Șan'à' and Bīša (today Saudi-Arabia), the caravans were guided by a constellation called al-dubb al-akbar (Ursa Major), especially by the three stars called Banāt $\mathrm{Na} \check{s}$ in Arabic, making up the drawbar of what in English is called The Plough. The issue of the use of stars for orientation in historic camel caravans would be a rewarding topic for further investigation.

\section{THE ORGANIZATION OF THE SOUTHERN CARAVANS}

Members of al-Hamdānī's own family were experienced in handling camels, as the author reveals (Iklīl 10, 199). His father traveled far, e.g. to Baghdad (șifa 197), to Kūfa, Baghdad, Basra, Omān, Egypt, and Mecca (al-Hamdān̄i 1974:200). In all likelihood, he either accompanied merchants' caravans or was a merchant himself (cf. Jâzim/Leclercq-Neveu 2001:4-9). In any case he traveled on exactly the long-distance routes that are described here. Consequently one has to assume that al-Hamdānī had some knowledge of camels, too, a fact that is clearly shown by the quotation I will give later. When he decided to write a book on The Two Precious Metals Gold and Silver, he had already written a volume on agriculture and another one on animal husbandry (called "kitāb al-ibil" or "book of camels"), both of which unfortunately are no longer extant. To complete this trilogy on property, he wrote The Two Precious Metals Gold and Sil-

\footnotetext{
5 The Arabic term manzil for a stopping place for camel caravans corresponds exactly to the Latin term mansio, which Pliny the Elder uses in describing the way from Thomna in southern Arabia to Gaza on the coast of the Mediterranean: "quod diuiditur in mansiones camelorum LXV" (Plinius Secundus 2002:397 = book 12, c.32, 64).
} 
ver, and in this, where one least expects it, he dealt extensively with the organization of a southern caravan. His descriptions are exact to a degree that sometimes they border on fussiness, but in most instances he gives the necessary explanations himself and leaves little to explain. I therefore want to cite the text for the larger part in my translation (al-Hamdānī 1969:48a-50a). The pieces of gold constituting the standard and other pieces to be weighed to the standard weight and to be thus prepared for minting are alternately arranged and compared with one another, because all should have the same weight: similar to the situation in Europe, coins were weighed at that time in South Arabia. This arrangement of the pieces of gold reminded alHamdānī of the organization of the South Arabian caravans, which he is setting out to describe as an example. In the process of writing, his description turned into a longer digression, in which the author could show his knowledge about camels and caravans embedded in an exhibit of his knowledge on minting:

What resembles the sequence of the row of the standard measure in the (melting) pot is the line up of the camels of the people of Yemen on their journeys. This is the case because most of their ways lead through plains full of thickets, brushes, fields, tangled trees and standing water or rugged ground full of discomfort and narrow passes.

al-Hamdānī characterizes the upper or highland route here quite convincingly: in changing from one fertile plain (e.g. al-Bawn north of the Yemeni capital) to the next one, the caravans had to traverse stony mountain passes (e.g. Naqīl al-Güla to the north of al-Bawn). On some of them one can see from the modern road that great efforts were made to construct passable roads there in earlier times.

The number of animals in such a caravan becomes clear in the following passage, since the author indicates it in his examples. At least one may presume that these numbers were not implausible for him.

They [people of Yemen] cannot arrange the rows of the camel-trains like the travelers from Iraq to Mecca and from Syria (in the desert), but their beasts of burden are always in a row, one camel after the other. Sometimes the length of a row reaches four or six miles according to the multitude of men and camels. For every thousand camels the space from the front and the space of the rows of men has an extent of two miles, two thousand (camels the extent of) four miles and three thousand six miles.

Consequently, a caravan made up of 1000 camels with the men leading them made up a continuous row nearly $4 \mathrm{~km}$ long; the author obviously wants us to imagine the men leading the camels walking between the animals. This length adds a special problem for caravans from the south: when the beginning was already at the station, the end of the caravan still had some hours more to travel:

And when the length of the camel-train brings it about, then the front is already in the manzil [stopping place], and the tail still has to travel there one marhala [distance of a day]. And when the front is at the manzil in the morning, the tail reaches it at noon, and when it is at the manzil in the evening, the tail reaches it at night time.

The organizers of these kinds of large trading caravans had to deal with what we would nowadays call logistic problems of traveling, transportation and supplies:

Concerning water, it [the tail] then finds only spittle and concerning fodder only waste, and sometimes it finds even nothing like that, in conjunction with the suffering it gets through thieves and raiders of the road and through indigent Bedus, who take advantage of it in the morning, following the company and their rear-guard closely.

The head of the caravan has the advantage of finding the best supplies of fodder and water at the stopping places, whereas the rearguard gets only the rest or nothing and is additionally molested by thieves, raiders and Bedus. This unequal allocation of risks and advantages calls for organization to establish a balance between the people, as al-Hamdānī comments: 
Consequently, they find the request inevitable to establish equal circumstances between the people or to work justice ${ }^{6}$ concerning their circumstances.

So they divide the caravan in four quarters, i.e. a multiplication of four with four. They do this according to the number of camels. Every day they let one quarter go first. On the next day, the rear guard precedes, and the first one from the day before becomes the second, the second one the third and the third one the rearguard. Then on the third day the third quarter, which was the rearguard of the second day, goes first, and the first of the day before, which was the rearguard, will become the first on the next day and the first of the first day becomes the second, and the second becomes the fourth, the rearguard. Then this rearguard precedes on the fourth day and becomes the first, whereas originally it was the second. Correspondingly, each quarter is further divided according to this system.

An example of this: "If a caravan consists of 1600 camels, the quarter is 400 , the quarter of that 100 and the quarter of the quarter of the quarter 25 . Then the men of one quarter meet and cast the lot. To whom the first lot is assigned, is the first. Thereafter the rest casts the lot, and to whom the first lot is assigned, is the second. Thereafter the men of the other two quarters cast the lot, and to whom it is assigned, is the third, and the forth is the rear guard."

\begin{tabular}{|c|c|c|c|c|c|c|c|c|}
\hline $\begin{array}{c}\text { 1st } \\
\text { station }\end{array}$ & 2nd & 3rd & 4th & 5th & 6th & 7th & 8th & 9th \\
\hline A & P & K & H & A & P & K & H & A \\
B & M & L & E & B & M & L & E & B \\
C & N & I & F & C & N & I & F & C \\
D & O & J & G & D & O & J & G & D \\
\hline E & D & O & J & G & D & O & J & E \\
F & A & P & K & H & A & P & K & F \\
G & B & M & L & E & B & M & L & G \\
H & C & N & I & F & C & N & I & H \\
\hline I & H & C & N & I & F & C & N & I \\
J & E & D & O & J & G & D & O & J \\
K & F & A & P & K & H & A & P & K \\
L & G & B & M & L & E & B & M & L \\
\hline M & L & G & B & M & L & E & B & M \\
N & I & H & C & N & I & F & C & N \\
O & J & E & D & O & J & G & D & O \\
P & K & F & A & P & K & H & A & P \\
\hline
\end{tabular}

Table 9: Schematic presentation of the organization of caravans by al-Hamdānī: the systematic change of quarters (indicated by different shades of gray) and quarters of quarters (letters A-P) at the caravan stations provided a fair distribution of the dangers and advantages of traveling in a caravan.

Following this example, the author makes an interesting digression about how the lots were cast to appoint the starting order of the groups on the first day of traveling, an advantageous day for the leading group and a rather dangerous and difficult one for the last:

There are some who write on four stones or on four sticks for making fire or arrows on one QDD, the sign for the leading one, on the second TNN, the sign of the second, on the third TLL, the sign of the third, and on the forth SQ, the sign of the rearguard, or RBB, the sign of the fourth. ${ }^{7}$ Sometimes they discern among them stones, or the people of each quarter bring an arrow without feathers and head, which is recognized. They collect all of them and hand them over to the lot-thrower. He takes the arrow-shafts or shakes the stones with raised head and fixed glance. Then he takes one of them out and says: "This is the first." And he is recognized. Then he takes out and says: "This is the second." And

\footnotetext{
6 The author uses verbs of the root s-w-y (VIII: "he sought, or desired, what was equal, equable, uniform, even" Lane 1863/93:1477f) and '-d-1 (I: he acted equitably, justly, or rightly; or II: "he made it equal" Lane 1663/93:1972f).

7 The signs are shorthand for the Arabic roots concerned: "he made foremost" is q-d-m, qaddama (Lane 1863/93:2985), "to call the second" t-n-y, tannā (Lane 1863/93:357), to call the third t-1-ta tallata (Lane 1863/93:347) and "to be the rearguard" s-w-q, sāqa (Lane 1863/93:1470f), exchangeable with "to call the fourth" r-b-', rabba' $a$ (Lane 1863/93:1016). The author uses the first two radicals of the roots concerned, e.g. instead of q-d-m only q-d-d, and so on.
} 
he is recognized. Then he takes out and says: "This is the third." And he is recognized. And the fourth one becomes the rearguard. And each quarter is divided up in (further) quarters along this division."

This is a description of the very common process of throwing the lot, as it had been known to the people from Palmyra in the north to South Arabia since pre-Islamic times. Originally, lots were thrown not only in everyday situations like the one mentioned here, but in connection with religious procedures such divination (Hoyland 2001:155-156). This last mentioned use of the lot was and still is forbidden in Islamic times. The author tries a further explanation of how the quarters of a caravan change daily. Evidently, he was not sure if his first explanation was clear enough:

Then they cover this marhala [distance of a day] according to the outcome of the lots, until they show up in the manzil [stopping place]. When they set out again, the rear guard has the leading part, that is, the quarter RBB, and the last quarter of this rear guard of yesterday, of the last quarter, becomes the first [quarter]of the first, of the leading one. And the quarter QDD becomes the second, and the quarter TNN the third, and the quarter TLL the fourth. Then they set out again after the second marhala, and the quarter TLL leads, the quarter RBB becomes the second, the quarter QDD the third and the quarter TNN the fourth. Then they go away from the third marhala, and the quarter TNN leads the way, the quarter TLL follows as second, the quarter RBB as third, and the quarter QDD becomes the rear guard. Then they go away from the fourth marhala in the same pattern in which they set out from their homes, and the first is the first (again), the second the second, the third the third and the fourth the fourth. The quarters adopt this in their quarters and (further) quarters according to this division.

A further problem comes to the author's mind now: What happens if the number of marāhil was not divisible by four:

And if their marāhil are four or eight or twelve or a multiple of four with any number, the quarters of it are equal to each other. But if something other is the case, then [one proceeds] with a marhala called "the pay of the foot" [ajr as-sāq] and "the curtailed one". But sometimes they count their marāhil and decide unanimously for manäzil exactly in accordance with them, and when they find them, they impose as an obligation that according to $\ldots{ }^{8}$ there. Sometimes they favor one of them and distribute it among themselves, and in the same manner the second and the third, and there is no division between them.

If the number of marāhil was not divisible by four, there were two possibilities of achieving a balance: the people introduced a shorter additional day's distance, or they united two groups for one of the marăhil on the way. A third attempt at an explanation follows, where the author uses combinations of letters from the Arabic alphabet:

As an example of this we make as a sign for the first quarter of the caravan a quadri-radical name, so that each letter of it becomes a sign for the quarter of a quarter; it is ABJD. ${ }^{9}$ And the sign for the second quarter of the caravan is KLMN, and the sign for the third quarter S'FS, and the sign for the fourth quarter QRŠT. This is a picture of that in the first day's journey and what follows:

The author's third effort at an explanation leads to his decision to present a table from which the change of the quarters can be read. I replaced Arabic by Latin letters (see table 9) using the sequence of the Latin alphabet.

And if each quarter of a quarter is divided by four, meaning the multiplication of four by four by four, of which the sum is 64, then the sum of this number becomes what is ABJD, KLMN, S'FS, and QRŠT, quarter after quarter, and the second, the third and the forth does the same, and then the division, which made the round in the one instance in four days, makes it now in 16 days. Know it!

With this "know it!" the author ends his digression on the organization of the southern caravans.

\footnotetext{
${ }^{8}$ Lacuna in the text.

9 al-Hamdānī has to introduce quadriradical combinations of letters to be able to denote the quarters and the quarters of the quarters of the caravan's units. The combinations of letters give no sense.
} 


\section{CONCLUSIONS}

Apart from water and fodder, caravans traveling through deserts had relatively minor problems compared to the caravans using a road through sometimes densely inhabited, agricultural regions alternating with mountainous, rocky, difficult terrain. These kinds of route necessitated a very deliberate organization, where risks and advantages were distributed in a balanced, equitable way among the participants of a caravan.

In my view, al-Hamdānī’s "thick description" ${ }^{10}$ relates to actual practices that were widespread enough in his time to be discussed for urban readers in such a detailed manner. Yet it is remarkable that al-Hamdānī treated readers anticipating information about gold and silver with this lengthy digression on the organization of caravans.

Apart from its comparative function, the whole passage perhaps is intended to accentuate the people of South Arabia's ingenious, elaborate methods for organizing caravans. At the center of their efforts was the desire to spread the dangers and the advantages of traveling in a caravan in the mountainous regions of South Arabia as equitably as possible. These attempts at a fair treatment of all participants were apparently not dictated by a Sulțān, Imām or another "top down" version of government, but were developed in "bottom up" ways by the people - traders, pilgrims - themselves: they can already be seen as small-scale attempts at democracy in the 10th century. The ideals of istiswā' (equal, equable distribution) and of 'adl (equity, justice, rectitude) are at the same time central values of tribal societies in South Arabia, with 'adl especially being an indispensable quality ascribed to leading personalities in this social environment. In addition, one has the feeling that similar to other fields of activities in South Arabia, such as animal husbandry, irrigation techniques or customary law, a very long experience preceded the ingenious regulations concerning equal distribution of risks and favors (cf. Serjeant 1984:36). It is just this ever present sense of justice and equality that is one of the main bonds holding together the members of the Yemeni tribal societies.

\section{REFERENCES}

Barfield, T (1997): The Dictionary of Anthropology. Oxford etc.: Blackwell

Bulliet, RW (1990): The Camel and the Wheel. New York: Columbia University Press

de Maigret, A 1997: “The Frankincense Road from Najrān to Ma'ān: A hypothetical itinerary”, in: Avanzini, A (ed.): Profumi d'Arabia: Atti del Convegno. Rome: "L’Erma” di Bretschneider, pp. 315-331

de Maigret, A (2003): "La route caravanière de l'encens dans l'Arabie Préislamique, in: Chroniques Yéménites 11. http://cy.revues.org/32, consulted 15 Feb., 2011

Groom, N (1981): Frankincense and Myrrh: A Study of the Arabian Incense Trade. London/New York/Beirut: Longman/Librairie du Liban

Halm, H (1991): Das Reich des Mahdi: Der Aufstieg der Fatimiden (875-973). Munich: CH Beck

al-Hamdānī (1949): Kitāb al-Iklīl al-Kitāb al- 'Āšir. (ed. Muḥibb al-Dīn al-Khatīb) Cairo: al-Maṭba'a al-Salafiyya

--- (1969): Kitāb al-Jawharatayn al- 'Atīqatayn min al-Șafrā' wa-al-Bayḍā'. Die beiden Edelmetalle Gold und Silber. (ed. Christopher Toll) Uppsala: Acta Universitatis Upsaliensis (Studia Semitica Upsaliensia 1)

--- (1974): Sifat Jazīrat al- 'Arab. (ed. Muḥammad b. 'Alī al-Akwa` al-Hiiwālī) al-Riyāḍ: Manšūrāt Dār al-Yamāma lial-Baḥt wa-al-Tarjama wa-al-Našr

Hinz, W (1991): "dhirā'”, entry in: Lewis, Bernard et al. (eds.): The Encyclopedia of Islam. New Edition. Leiden: Brill, Vol. 2, pp. 231-232

Hoyland, RG (2001): Arabia and the Arabs from the Bronze Age to the Coming of Islam. London/New York: Routledge

Ibn al-Mujāwir (1986): Șifat Bilād al-Yaman wa-Makka wa-ba'ḍ al-Hijāz al-Musammā Tārīhal-Mustabșir (ed. Oskar Lofgren). Beirut: Manšūrāt al-Madīna

${ }^{10}$ This thick description is a rather nice - and old - example for a kind of writing "in which, through a careful attention to detail and context, there is an integration of description with interpretation." (Barfield 1997:466). This use of the term was popularized by Clifford Geertz. 
Jâzim, Muhammad 'Abd al-Rahîm/Leclercq-Neveu, B (2001): "L'organisation des caravanes au Yémen selon alHamdânî (Xe siècle)”, in: Chroniques Yéménites 9. http://cy.revues.org/32, consulted 15 Feb., 2011

Lane, EW (1863/93): Madd al-qāmūs: An Arabic-English Lexicon, Derived from the Best and the Most Copious Eastern Sources. London/Edinburgh: Williams and Norgate

Plinius Secundus, Gaius (2002): Naturalis Historia. (eds. Jan, L/Mayhoff, C) Munich/Leipzig: KG Saur

Al-Rashid, Saad A (1980): Darb Zubaydah: The Pilgrim Road from Kufa to Mecca. al-Riyāḍ: Riyad University Libraries

Serjeant, RB (1984): “The Cultivation of Cereals in Medieval Yemen”,in: Serjeant, RB/Bidwell, RL (eds.): Arabian Studies I. London: C Hurst \& Co., pp. 25-74

Trevor-Roper, H (1983): "The Invention of Tradition: The Highland Tradition of Scotland", in: Hobsbawm, E/Ranger, T (eds.): The Invention of Tradition. Cambridge: Cambridge University Press, pp. $15-41$

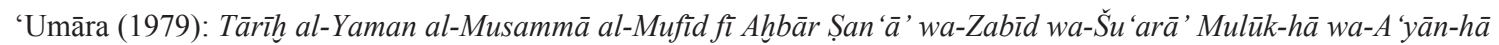
$w a-U d a b \bar{a}$ '-hā. (ed. Muhammad b. 'Alī al-Akwa' al-Ḥiwālī) (2nd edition) n.p.: Maṭba'at al'Ilm 
